Article

\title{
In Vitro Tetraploid Induction from Leaf and Petiole Explants of Hybrid Sweetgum (Liquidambar styraciflua $\times$ Liquidambar formosana)
}

\author{
Yan Zhang ${ }^{1}$, Zewei Wang ${ }^{1}$, Shuaizheng $\mathrm{Qi}^{1}{ }^{1}$, Xiaoqi Wang ${ }^{1}$, Jian Zhao ${ }^{1}$, Jinfeng Zhang ${ }^{1, *}$, \\ Bailian $\mathrm{Li}^{1,2}$, Yadong Zhang ${ }^{3}$, Xuezeng Liu ${ }^{3}$ and Wei Yuan ${ }^{4}$ \\ 1 Beijing Advanced Innovation Center for Tree Breeding by Molecular Design, National Engineering \\ Laboratory for Tree Breeding, Key Laboratory of Genetics and Breeding in Forest Trees and Ornamental \\ Plants of Ministry of Education, Key Laboratory of Forest Trees and Ornamental Plants Biological \\ Engineering of State Forestry Administration, College of Biological Sciences and Technology, \\ Beijing Forestry University, Beijing 100083, China; zhangyan19890802@126.com (Y.Z.); \\ linxuewzw@163.com (Z.W.); 13051857171@163.com (S.Q.); liqiu8826623@163.com (X.W.); \\ lbyyuanwei@163.com (J.Z.); Bailian_Li@ncsu.edu (B.L.) \\ 2 Department of Forestry and Environmental Resources, North Carolina State University, Raleigh, \\ NC 27695, USA \\ 3 Henan Longyuan Flowers \& Trees Co., Ltd., Yanling 461200, China; lyhmkjb@163.com (Y.Z.); \\ lxuezeng@126.com (X.L.) \\ 4 Zhengzhou China Green Expo Garden, Zhengzhou 451460, China; lbyyuanwei@163.com \\ * Correspondence: zjf@bjfu.edu.cn
}

Received: 4 June 2017; Accepted: 20 July 2017; Published: 28 July 2017

\begin{abstract}
Liquidambar is an important forestry species used to generate many commercial wood products, such as plywood. Inducing artificial polyploidy is an effective method to encourage genetic enhancements in forestry breeding. This report presents the first in vitro protocol for the induction of genus Liquidambar tetraploids based on the established in vitro regeneration system of hybrid sweetgum (Liquidambar styraciflua $\times$ Liquidambar formosana). The leaves and petioles from three genotypes were pre-cultured in woody plant medium (WPM) supplemented with $0.1 \mathrm{mg} / \mathrm{L}$ thidiazuron (TDZ), $0.8 \mathrm{mg} / \mathrm{L}$ benzyladenine (BA), and $0.1 \mathrm{mg} / \mathrm{L} \alpha$-naphthalene acetic acid (NAA) for a variable number of days ( 4,6 or 8 days), and exposed to varying concentrations of colchicine $(120,160,200 \mathrm{mg} / \mathrm{L})$ for 3,4 or 5 days; the four factors were investigated using an orthogonal experimental design. Adventitious shoots were rooted in 1/2 WPM medium supplemented with $2.0 \mathrm{mg} / \mathrm{L}$ indole butyric acid (IBA) and $0.1 \mathrm{mg} / \mathrm{L}$ NAA. The ploidy level was assessed using flow cytometry and chromosome counting. Four tetraploids and nine mixoploids were obtained from the leaves. Pre-treatment of the leaves for 8 days and exposure to $200 \mathrm{mg} / \mathrm{L}$ colchicine for 3 days led to the most efficient tetraploid induction. Producing 11 tetraploids and five mixoploids from petioles, the best tetraploid induction treatment for petioles was almost the same as that with the leaves, except that pre-culturing was required for only 6 days. In total, 15 tetraploids were obtained with these treatments. This study described a technique for the induction of tetraploid sweetgum from the leaves or petioles of parental material. Based on the success of polyploid breeding in other tree species, the production of hybrid sweetgum allotetraploids constitutes a promising strategy for the promotion of future forestry breeding.
\end{abstract}

Keywords: chromosome doubling; sweetgum; allotetraploid 


\section{Introduction}

Liquidambar styraciflua, belonging to the genus Liquidambar, is found widely in the southern regions of the United States. L. styraciflua has become one of the most important commercial hardwoods in the United States [1,2], because it has a fast growing rate and provides many useful materials such as wood, plywood, pulp and paper production [2]. Liquidambar formosana, mainly distributed in East Asia, is an important tree in China owing to its fast-growing properties and use in timber and medicinal production and landscaping [3]. Interestingly, L. styraciflua can be interfertile with L. formosana [4,5]. Due to the potential of heterosis from interspecies hybridisation, hybrid sweetgum can show robust growth [5].

Allopolyploids are the products of merging two or more genomes by intraspecific or interspecific hybridisation [6,7]. Allopolyploid breeding has been applied successfully in forestry due to its advantages of high biomass and fitness. In vitro regeneration using the reproductive organs of woody plants has been successful in many species. Induction of tetraploidy has been successful in a number of species, including Populus [8,9], Paulownia tomentosa [10], and Citrus [11]. Unlike meiotic (sexual) chromosome doubling, in vitro asexual polyploidy breeding is not limited by season, and it benefits from a low mixoploids-inducing rate; it has been applied widely in forestry breeding.

Successful induction of tetraploids has been achieved using various chemical reagents, such as colchicine [12], oryzalin [13], and trifluralin [14]. Colchicine is the most widely applied chemical for in vitro tetraploid induction. Moreover, many explant types have been used as materials for in vitro polyploidy induction, such as leaves [8], petioles [15], calluses [12], shoots [16], hypocotyl segments, and cotyledonary nodes [17]. Although leaves and petioles are not used commonly as explants for tetraploid induction, they exhibit a high tetraploid-inducing rate and low number of mixoploids, indicating that they can be used for efficient polyploidy breeding $[9,18]$. We have improved the media that were applied to the in vitro regeneration of L. styraciflua $[19,20]$ and L. formosana [21], and the modified medium was suitable for establishing an efficient regeneration system from leaves and petioles of hybrid sweetgum (L. styraciflua $\times$ L. formosana). Therefore, it is possible to acquire in vitro colchicine-induced tetraploid sweetgum.

This study describes an efficient method for the in vitro induction of tetraploids. First, we established multiple hybrid sweetgum genotypes. Then, we investigated the effects of explant type, explant genotype, time of pre-incubation, time of colchicine treatment and concentration of colchicine using an orthogonal experimental design. The tetraploids were determined by flow cytometry and chromosome counting. We hope that the biomass, resistance and ornamental value of Liquidambar will be improved by chromosome doubling after in vitro colchicine treatment.

\section{Materials and Methods}

\subsection{Plant Materials}

Floral branches of the male parent (L. formosana) were collected from five genotypes at Shanghai Chen Shan Botanical Garden (Songjiang District, Shanghai, China); pollen was collected; the same volume of pollen was measured and they were mixed together. In April, the male inflorescences of L. styraciflua were removed, and controlled pollination was applied to acquire hybrid seeds by pollination with the pollen of L. formosana. L. styraciflua was grown at the Shanghai Chen Shan Botanical Garden (Songjiang District, Shanghai, China). The fruits were collected in mid-September 2015, and the seeds were stored at $4^{\circ} \mathrm{C}$.

\subsection{Establishment of Aseptic Seedlings and In Vitro Multiplication}

Plump seeds were selected and sterilised in $75 \%$ ethanol $(v / v)$ for $45 \mathrm{~s}$, rinsed once with sterile distilled water followed by $2 \%$ sodium hypochlorite for $8 \mathrm{~min}$, and then washed three times with sterile distilled water. The seeds were added to basal woody plant medium (WPM) supplemented with $4 \mathrm{~g} / \mathrm{L}$ agar and $2 \mathrm{~g} / \mathrm{L}$ polygel, and $30 \mathrm{~g} / \mathrm{L}$ sucrose (pH 5.8-5.9) in a 9-mm culture dish; no phytohormone 
was added; in this experiment, all media were semi-solidified. After 20 days, the germinated seedlings were placed in magenta boxes with $50 \mathrm{~mL}$ basal WPM [22]. A total of 150 plant genotypes were sub-cultured in rooting medium containing half-strength WPM medium supplemented with $2.0 \mathrm{mg} / \mathrm{L}$ indole butyric acid (IBA) and $0.1 \mathrm{mg} / \mathrm{L}$ naphthalene acetic acid (NAA). Regeneration medium for leaves and petioles consisted of WPM medium with $0.1 \mathrm{mg} / \mathrm{L} \mathrm{TDZ}, 0.8 \mathrm{mg} / \mathrm{L}$ benzyladenine (BA) and $0.1 \mathrm{mg} / \mathrm{L}$ NAA supplemented with $2 \mathrm{~g} / \mathrm{L}$ agar and $4 \mathrm{~g} / \mathrm{L}$ double coagulation, and $30 \mathrm{~g} / \mathrm{L}$ sucrose. After 40 days, the explants were transferred into elongation medium supplemented with WPM basal salts, $0.4 \mathrm{mg} / \mathrm{L} \mathrm{BA}$ and $0.1 \mathrm{mg} / \mathrm{L} \mathrm{NAA}$; the concentrations of agar and double coagulation were changed to $2 \mathrm{~g} / \mathrm{L}$ agar and $2 \mathrm{~g} / \mathrm{L}$, respectively.

Three hybrid plant genotypes (named Z1, Z2, and Z3) were selected for tetraploid induction (Table 1). The shoot-inducing rate of all leaves and petioles reached $85 \%$, and they displayed similar morphological characteristics during development.

Shoot-inducing rate: Number of adventitious shoots $(\geq 1 \mathrm{~cm}) /$ number of explants $\times 100 \%$

Table 1. Influencing factors and level values.

\begin{tabular}{ccccc}
\hline & \multicolumn{4}{c}{ Factors } \\
\cline { 2 - 5 } Levels & A & B & C & D \\
\cline { 2 - 5 } & Genotype & $\begin{array}{c}\text { Colchicine } \\
\text { Concentration (mg/L) }\end{array}$ & $\begin{array}{c}\text { Pre-Culture } \\
\text { Duration (day) }\end{array}$ & $\begin{array}{c}\text { Exposure Time } \\
\text { (day) }\end{array}$ \\
\hline 1 & Z1 & 120 & 4 & 3 \\
2 & Z2 & 160 & 6 & 4 \\
3 & Z3 & 200 & 8 & 5 \\
\hline
\end{tabular}

\subsection{Colchicine Application}

After sub-culturing for 60 days, the second and third leaves and petioles of Z1, Z2, and Z3 were selected as the materials for colchicine treatment. The leaf samples were proximal halves cut twice through the main vein, and the petioles were cut into $0.8-1.0 \mathrm{~cm}$ pieces; both sample types were pre-cultured in WPM supplemented with $0.1 \mathrm{mg} / \mathrm{L} \mathrm{TDZ,} 0.8 \mathrm{mg} / \mathrm{L} \mathrm{BA}$ and $0.1 \mathrm{mg} / \mathrm{L}$ NAA for 4,6 , or 8 days, and then treated for 3,4 or 5 days with various concentrations of colchicine (120, 160 or $200 \mathrm{mg} / \mathrm{L})$. The genotype, number of days of pre-incubation, colchicine exposure time, and concentration of colchicine were included as variables in the $\mathrm{L}\left(9_{3}\right)^{4}$ orthogonal experimental design (Table 1); two explant types, leaf and petiole were applied to the same design, respectively. Cultures with colchicine treatment were performed in $100 \mathrm{~mL}$ flasks and incubated at $25 \pm 2{ }^{\circ} \mathrm{C}$, under dark conditions. Adventitious shoots longer than $1.5 \mathrm{~cm}$ were harvested and placed into the rooting medium.

Explants survival rate: Number of survival explants (leaf or petiole)/all explants $\times 100 \%(n=3)$

\subsection{Flow Cytometric Analysis of Ploidy Level}

We collected leaves that were growing vigorously in vitro, and the ploidy level was analysed by Cyflow Ploidy Analyser (Partec, Görlitz, Germany). The leaves were chopped with a sharp razor blade (Gillette, Boston, MA, USA) in a plastic dish containing $1.25 \mathrm{~mL}$ of modified Galbraith's buffer (9.15 g/L MgCl $2 \cdot 6 \mathrm{H}_{2} \mathrm{O}, 4.19 \mathrm{~g} / \mathrm{L} \mathrm{3-(N-morpholino)} \mathrm{propansulfonic} \mathrm{acid} \mathrm{(MOPS),} 8.82 \mathrm{~g} / \mathrm{L}$ sodium citrate, $0.1 \%$ polyethylene glycol p-(1,1,3,3-tetramethylbutyl)-phenyl ether (Triton X-100), pH 7.0). The crude nuclei solution was filtered through a 50- $\mu$ m nylon filter. Subsequently, the leachate was stained with $100 \mu \mathrm{L} 4^{\prime}$,6-diamidino-2-phenylindole (DAPI, $10 \mu \mathrm{g} / \mathrm{mL}$ ) for $10 \mathrm{~s}$ to detect the ploidy level. Leaves from the diploid full-sib family were used as a control to adjust the number of DAPI channels to 50. Sub-culturing was performed twice over a 5-month period, and the ploidy level was examined 
twice in this period. Finally, tetraploids, mixoploids, and diploids were placed vertically into Jiffy Mix (Shippagan, NB, Canada). After 2 months, the plants were transferred into plastic pots (height: $12 \mathrm{~cm}$, top width: $10 \mathrm{~cm}$, bottom width: $9.25 \mathrm{~cm}$ ) containing a 2:1:1 sterilised mixture of peat, vermiculite, and perlite (autoclaved at $121{ }^{\circ} \mathrm{C}$ for $30 \mathrm{~min}$ ). After 2 months, the final ploidy level was determined.

\subsection{Chromosome Counting}

Shoot growth occurred in rooting medium for nearly 2 weeks, and 5-10 $\mathrm{mm}$ of the root tips were examined. The root tips were rinsed and fixed in Carnoy's solution [23] for $24 \mathrm{~h}$ at $4{ }^{\circ} \mathrm{C}$. After washing three times, the root tips were hydrolysed in $1 \mathrm{~N} \mathrm{HCl}$ for $15 \mathrm{~min}$ at $60^{\circ} \mathrm{C}$, then the root tips were washed three times for $5 \mathrm{~min}$. The treated root tips were cut into $\sim 1.5 \mathrm{~mm}$ sections, stained with 1 drop of carbol fuchsin [24] solution for $15 \mathrm{~min}$, and observed with a microscope using a $100 \times$ oil immersion lens (Olympus, Tokyo, Japan).

\subsection{Statistical Analysis}

Range analysis was used to evaluate the importance of each factor. The value of Range $(\mathrm{R}=k \cdot(\max )-k(\mathrm{mix}) ;)$ and $k_{\mathrm{x}}$ were positively related to the importance of the factors and levels, respectively. The significance of differences among the treatments were evaluated using the homogeneity test and analysis of variance (ANOVA) using SPSS statistical software (ver. 18.0; SPSS Inc., Chicago, IL, USA). $P<0.05$ was considered to indicate statistical significance. Arcsine transformation $\left(\theta=\sin ^{-1} \sqrt{P} \theta\right.$ : angle, $P$ : percentage) to determine percentages before ANOVA was performed using Microsoft Excel 2010 software (Microsoft Corp., Washington, DC, USA).

\section{Results}

\subsection{Morphologic Observations in the Initial Stage of Regeneration}

Less than $10 \%$ of the cultures were contaminated, and 150 genotypes of hybrid sweetgums were established in vitro and sub-cultured. Three genotypes were selected for colchicine treatment. The leaves of the hybrid sweetgum were trisected during the early stage. After incubation for 4 days, no nodules were observed on the wound of the main vein of the leaves and petioles. From 4 to 6 days, nodules appeared and expanded rapidly, and growth continued until 8 days. The nodules in the leaves near the petioles were larger than those found on other wounds (Figure 1). The first bud appeared nearly 20 days after the shoot explants were placed in medium. 


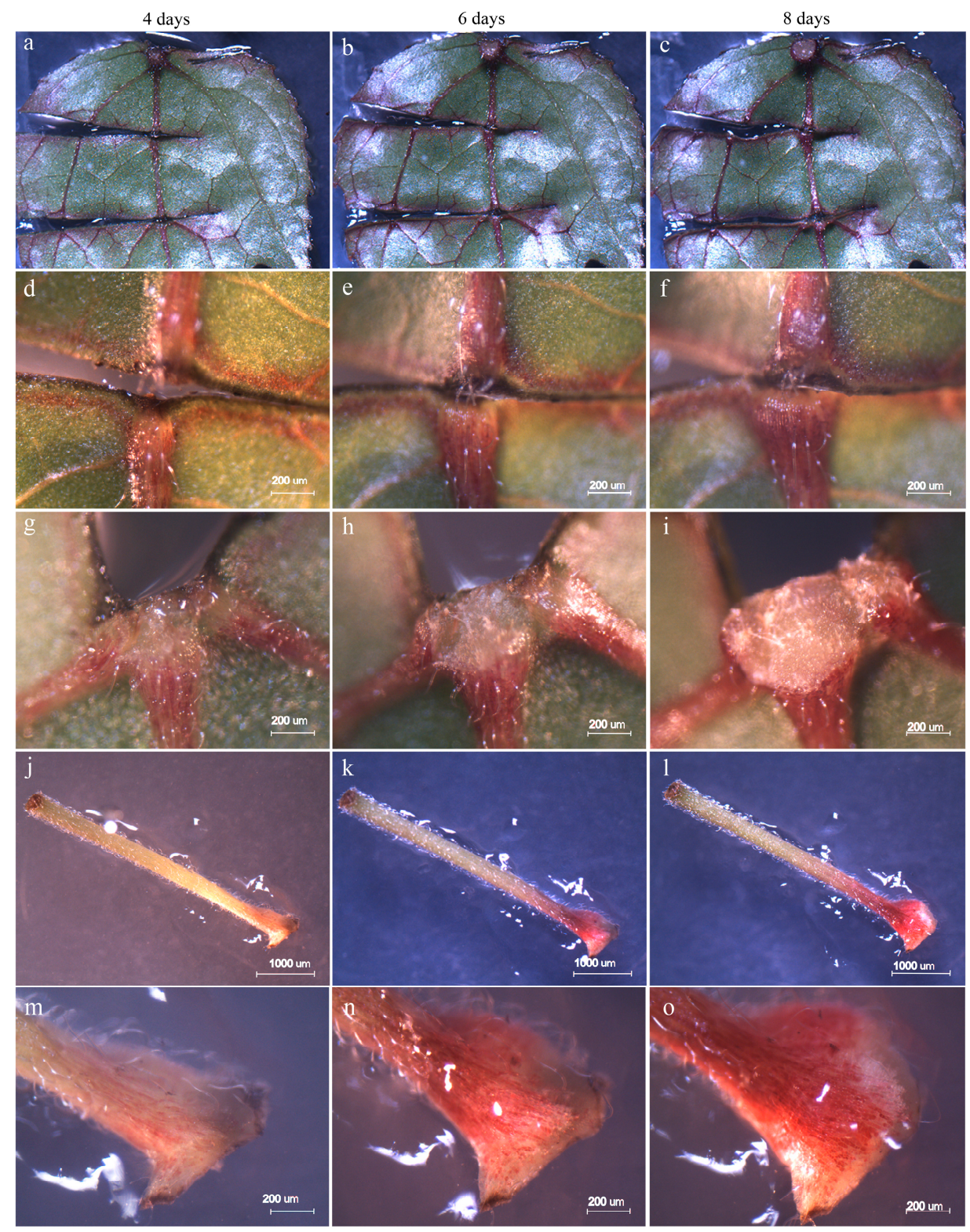

Figure 1. Morphology of leaves and petioles cultured in regeneration medium after 4, 6, and 8 days. (a-c) morphology of leaves cultured for 4,6 , and 8 days, respectively; (d-f) morphology of the second wound in the leaf main vein at 4,6, and 8 days respectively; (g-I) morphology of the first wound in the leaf main vein at 4,6 , and 8 days, respectively; $(j-1)$ morphology of the petiole cultured for 4,6 , and 8 days, respectively; (m-o) morphology of one end of the petiole cultured for 4,6 , and 8 days, respectively.

\subsection{Survival Rate and Regeneration of Colchicine-Treated Explants}

Under treatment 4 , the survival rates were $<10 \%$ (Tables 2 and 3). Table 4 shows that the concentration of colchicine (120-200 mg/L) had no significant effect on the survival rate of leaf explants. In contrast, genotype, pre-culture time and exposure time had significant effects on the survival rate in leaves (Table 4) and in petioles (Table 5). Exposure time exerted the most significant effect on survival rate for both leaves and petioles (Table 6). 
Table 2. Design of orthogonal table $\mathrm{L}_{9}(3)^{4}$ for leaves.

\begin{tabular}{|c|c|c|c|c|c|c|c|c|c|}
\hline \multirow{2}{*}{ Treatment } & \multicolumn{4}{|c|}{ Factors } & \multirow{2}{*}{$\begin{array}{l}\text { Number of Shoots } \\
\text { Examined }\end{array}$} & \multirow{2}{*}{$\begin{array}{l}\text { Survival } \\
\text { Rate \% }\end{array}$} & \multirow{2}{*}{$\begin{array}{c}\text { No. of } \\
\text { Tetraploid }\end{array}$} & \multirow{2}{*}{$\begin{array}{c}\text { No. of } \\
\text { Mixoploid }\end{array}$} & \multirow{2}{*}{$\begin{array}{c}\text { Tetraploid } \\
\text { Induction \% }\end{array}$} \\
\hline & A & B & $\mathrm{C}$ & D & & & & & \\
\hline $\mathrm{c} 1$ & 1 & 1 & 1 & 1 & 50 & 95.00 & 1 & 1 & 2.00 \\
\hline c2 & 1 & 2 & 2 & 2 & 50 & 75.00 & 0 & 1 & 0.00 \\
\hline c3 & 1 & 3 & 3 & 3 & 30 & 41.67 & 1 & 2 & 3.33 \\
\hline c4 & 2 & 1 & 2 & 3 & 15 & 8.33 & 0 & 0 & 0.00 \\
\hline c5 & 2 & 2 & 3 & 1 & 50 & 81.67 & 1 & 1 & 2.00 \\
\hline c6 & 2 & 3 & 1 & 2 & 50 & 90.00 & 0 & 1 & 0.00 \\
\hline c7 & 3 & 1 & 3 & 2 & 50 & 75.00 & 0 & 1 & 0.00 \\
\hline c8 & 3 & 2 & 1 & 3 & 50 & 70.00 & 0 & 0 & 0.00 \\
\hline c9 & 3 & 3 & 2 & 1 & 50 & 85.00 & 1 & 2 & 2.00 \\
\hline
\end{tabular}

Table 3. Design of orthogonal table $\mathrm{L}_{9}(3)^{4}$ for petioles.

\begin{tabular}{|c|c|c|c|c|c|c|c|c|c|}
\hline \multirow{2}{*}{ Treatment } & \multicolumn{4}{|c|}{ Factors } & \multirow{2}{*}{$\begin{array}{l}\text { Number of Shoots } \\
\text { Examined }\end{array}$} & \multirow{2}{*}{$\begin{array}{l}\text { Survival } \\
\text { Rate \% }\end{array}$} & \multirow{2}{*}{$\begin{array}{c}\text { No. of } \\
\text { Tetraploid }\end{array}$} & \multirow{2}{*}{$\begin{array}{c}\text { No. of } \\
\text { Mixoploid }\end{array}$} & \multirow{2}{*}{$\begin{array}{l}\text { Tetraploid } \\
\text { Induction \% }\end{array}$} \\
\hline & $\mathbf{A}$ & B & $\mathrm{C}$ & D & & & & & \\
\hline $\mathrm{c} 1$ & 1 & 1 & 1 & 1 & 50 & 85.00 & 1 & 0 & 2.00 \\
\hline c2 & 1 & 2 & 2 & 2 & 50 & 56.67 & 2 & 1 & 4.00 \\
\hline c3 & 1 & 3 & 3 & 3 & 30 & 28.33 & 1 & 0 & 3.33 \\
\hline c4 & 2 & 1 & 2 & 3 & 15 & 10.00 & 0 & 0 & 0.00 \\
\hline c5 & 2 & 2 & 3 & 1 & 50 & 56.67 & 3 & 2 & 6.00 \\
\hline c6 & 2 & 3 & 1 & 2 & 50 & 75.00 & 0 & 0 & 0.00 \\
\hline c7 & 3 & 1 & 3 & 2 & 50 & 48.33 & 0 & 0 & 0.00 \\
\hline c8 & 3 & 2 & 1 & 3 & 50 & 51.67 & 0 & 0 & 0.00 \\
\hline c9 & 3 & 3 & 2 & 1 & 50 & 70.00 & 4 & 2 & 8.00 \\
\hline
\end{tabular}

Table 4. The variation analyses of survival rates for different genotype leaves (Liquidambar styraciflua $\times$ L. formosana), concentration, pre-culture duration and exposure time.

\begin{tabular}{ccccc}
\hline Variation Source & $d f$ & MS & $\boldsymbol{F}$ & Sig. \\
\hline Genotype & 2 & 294.147 & 4.876 & $0.020^{*}$ \\
Concentration & 2 & 193.362 & 3.205 & 0.064 \\
Pre-culture duration & 2 & 1087.422 & 18.027 & $0.000^{*}$ \\
Exposure time & 2 & 2769.584 & 45.913 & $0.000^{*}$ \\
Error & 18 & 60.322 & & \\
Total & 27 & & & \\
\hline
\end{tabular}

$d f$ : degrees of freedom; MS: mean square; Sig.: significance; * Represents a significant difference at $p<0.05$.

Table 5. The variation analyses of survival rates for different genotype petioles (Liquidambar styraciflua $\times$ L. formosana), concentration, pre-culture duration and exposure time.

\begin{tabular}{ccccc}
\hline Variation Source & $d f$ & MS & $\boldsymbol{F}$ & Sig. \\
\hline Genotype & 2 & 138.765 & 6.238 & $0.009^{*}$ \\
Concentration & 2 & 97.631 & 4.389 & $0.028^{*}$ \\
Pre-culture duration & 2 & 811.981 & 36.502 & $0.000^{*}$ \\
Exposure time & 2 & 1612.270 & 72.478 & $0.000^{*}$ \\
Error & 18 & 22.245 & & \\
Total & 27 & & &
\end{tabular}

$d f$ : degrees of freedom; MS: mean square; Sig.: significance; ${ }^{*}$ Represents a significant difference at $p<0.05$. 
Table 6. The range analysis of the hybrid sweetgum survival rate by orthogonal test.

\begin{tabular}{cccccc}
\hline Explant Type & & A & B & C & D \\
\hline \multirow{5}{*}{ Leaf } & $K_{1}$ & 211.67 & 178.33 & 255.00 & 261.67 \\
& $K_{2}$ & 180.00 & 226.67 & 168.33 & 240.00 \\
& $K_{3}$ & 230.00 & 216.67 & 198.33 & 120.00 \\
& $k_{1}$ & 70.56 & 59.44 & 85.00 & 87.22 \\
& $k_{2}$ & 60.00 & 75.56 & 56.11 & 80.00 \\
& $k_{3}$ & 76.67 & 72.22 & 66.11 & 40.00 \\
& $R$ & 16.67 & 16.11 & 28.89 & 47.22 \\
\hline \multirow{5}{*}{ Petiole } & $K_{1}$ & 170.00 & 143.33 & 211.67 & 211.67 \\
& $K_{2}$ & 141.67 & 165.00 & 136.67 & 180.00 \\
& $K_{3}$ & 170.00 & 173.33 & 133.33 & 90.00 \\
& $k_{1}$ & 56.67 & 47.78 & 70.56 & 70.56 \\
& $k_{2}$ & 47.22 & 55.00 & 45.56 & 60.00 \\
& $k_{3}$ & 56.67 & 57.78 & 44.44 & 30.00 \\
& $R$ & 9.44 & 10.00 & 26.11 & 40.56 \\
\hline
\end{tabular}

R: Range. Range $=k \cdot(\max )-k(\operatorname{mix}) ; K_{1 \mathrm{~A}}=\mathrm{X}_{\mathrm{A} 1}+\mathrm{X}_{\mathrm{A} 2}+\mathrm{X}_{\mathrm{A} 3}, \mathrm{~K}_{2 \mathrm{~A}}=\mathrm{X}_{\mathrm{A} 4}+\mathrm{X}_{\mathrm{A} 5}+\mathrm{v} \mathrm{X}_{\mathrm{A} 6}, \mathrm{~K}_{3 \mathrm{~A}}=\mathrm{X}_{\mathrm{A} 7}+\mathrm{X}_{\mathrm{A} 8}+\mathrm{v} \mathrm{X}_{\mathrm{A} 9} \ldots$; $k_{\mathrm{x}}=K_{\mathrm{x}} /$ number of level.

\subsection{Analysis by Flow Cytometry and Polyploid Determination}

The ploidy levels were determined by three flow cytometry tests (Figure 2). The first test was administered in shoots that were rooted in medium for 1 month, the second test was administered after sub-culturing for 2 months, and the third test was administered after transplantation in the soil for 2 months. Therefore, the chromosomes were counted over a total of 6 months. The results showed that tetraploids and mixoploids were induced in the three genotypes of hybrid sweetgum (Tables 2 and 3). The most effective treatment for inducing polyploidy in the petioles was treatment 9 , which consisted of pre-culturing genotype Z3 for 6 days, followed by $200 \mathrm{mg} / \mathrm{L}$ colchicine treatment for 3 days. This treatment resulted in $8 \%$ tetraploid and $4 \%$ mixoploid induction rates (Table 3 ). For the leaves, one tetraploid was acquired in c1, c3, c5, and c9 (Table 2). The chromosome number of tetraploid hybrid sweetgum was $2 n=4 x=52$ (Figure 3a), and the chromosome number of diploids was $2 n=2 x=26$ (Figure $3 b$ ).
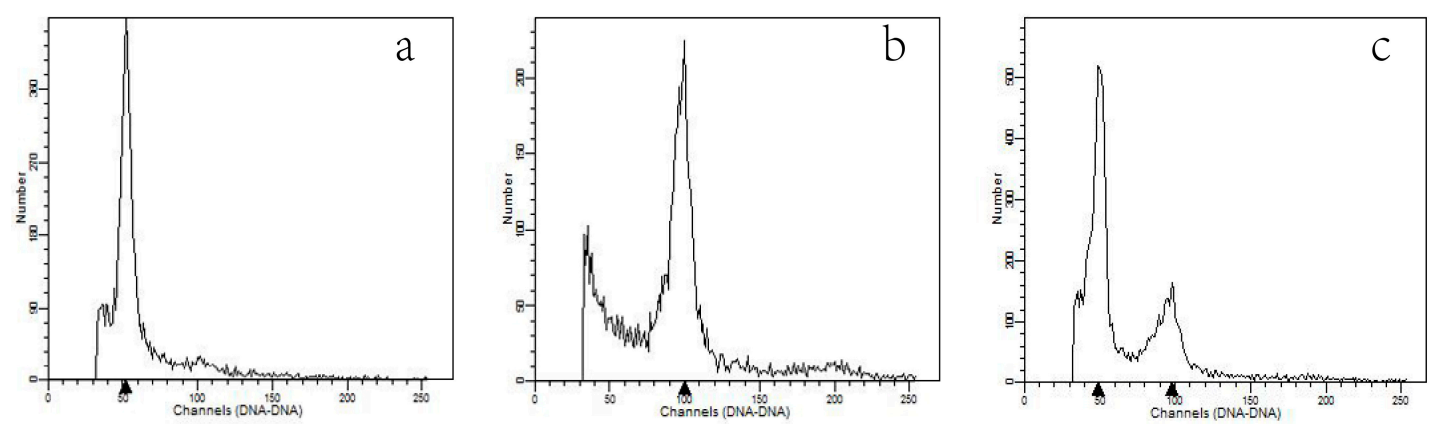

Figure 2. Histograms of flow cytometric analysis of Liquidambar styraciflua $\times$ Liquidambar formosana (a) diploid plant (control); (b) tetraploid plant; (c) diploid + tetraploid plant. 

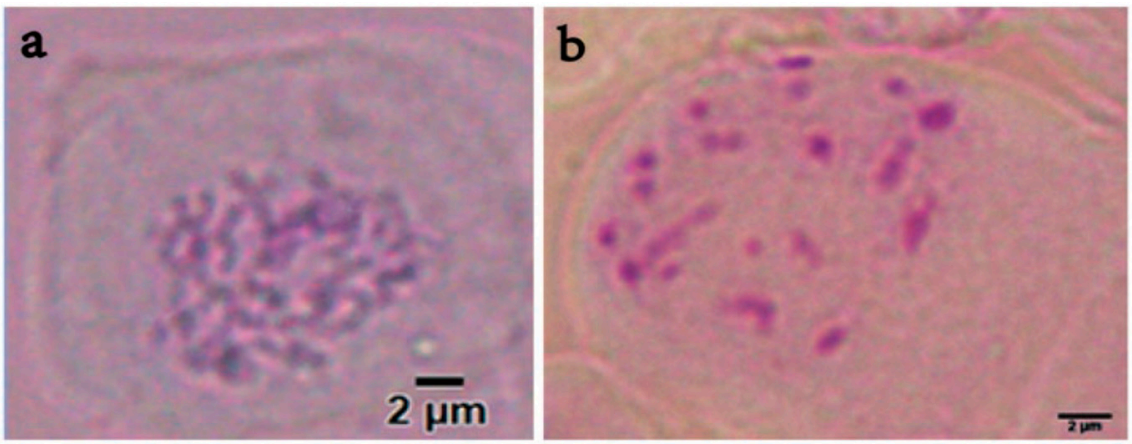

Figure 3. Chromosome counting of regenerated Liquidambar styraciflua $\times$ L. formosana plant (a) Chromosomes of a tetraploid plant. (b) Chromosomes of a diploid plant.

Range analysis of the results showed that the best concentration of colchicine and exposure time was $200 \mathrm{mg} / \mathrm{L}$ and 3 days, respectively, for both leaf and petiole explants. The number of tetraploids was lower than for those exposed to colchicine for 5 days (Table 7). Range analysis also showed that the exposure time was the most important influencing factor in leaf and petiole tetraploid numbers. Moreover, the morphology of the adventitious shoots of leaves were similar to that of petioles (Figure 4a,b), and tetraploid plantlets was significantly different from that found in the diploid plantlets, showing deeper green leaf colour and shorter root length and internodal distance (Figure 4c).

Table 7. The range analysis of the hybrid sweetgum tetraploid-inducing rate by orthogonal test.

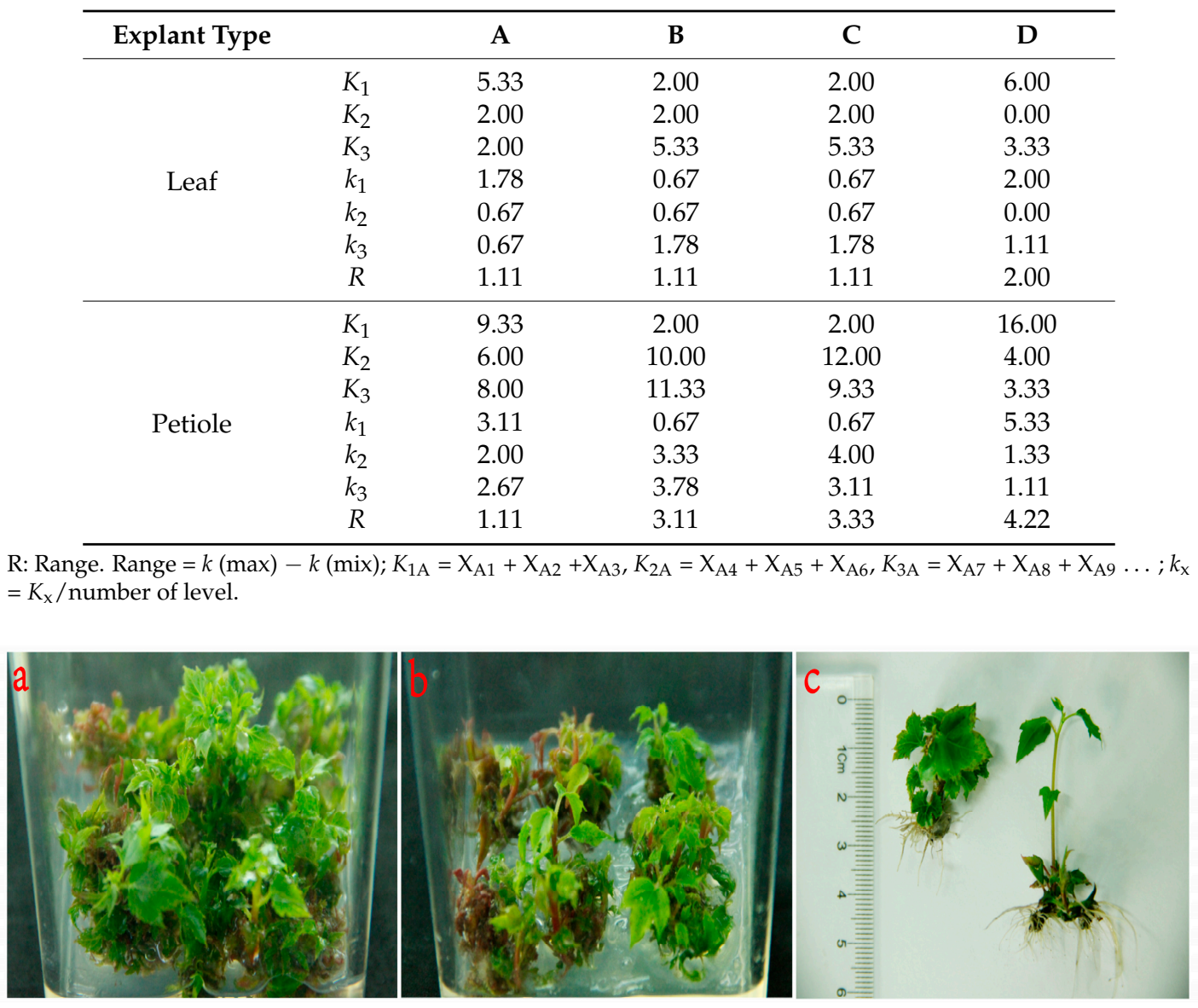

Figure 4. Morphology of shoot regeneration in Z3 leaves and petioles after 60 days. (a) leaf; (b) petiole; (c) tetraploid; (left) and diploid (right). 


\section{Discussion}

This study describes a method of in vitro tetraploid induction from leaf explants of hybrid sweetgum (L. styraciflua $\times$ L. formosana). Morphological mutation has been found in tetraploid plantlets. Interestingly, this phenomenon has appeared in herbs, fruit and timber trees $[9,11,18]$. In this paper, we investigated the effects of explant type, genotype, pre-incubation time, exposure time in colchicine and concentration of colchicine. The exposure time had the greatest effect on the tetraploid-inducing rate, this may be due to the lower survival rate of explants after over exposure to colchicine.

All three genotypes acquired tetraploids, with similar results to those obtained using Actinidia chinensis and Populus [8,15]. Few studies have considered both leaves and petioles together, perhaps due to limited efficiency of regeneration, such as in Actinidia chinensis [15]. Therefore, previous studies have provided no evidence as a basis for comparing the induction rates of leaves and petioles. In this study, the ability to induce tetraploidy was higher in petioles than in leaves. It is possible that the nine treatments were more suited to petioles, or the chromosomes and petiole cells were more responsive to colchicine treatment. This method has potential for successful acquisition of polyploids using a high-efficiency regeneration system for leaves and petioles of some plant species. In this study, we found lower induction rates for leaves and petioles pre-cultured for 4 days versus those pre-cultured for 6 or 8 days. Interestingly, we observed that the wounds in the main vein expanded slowly (Figure 1). The relationship between wound expansion and induction rate requires further confirmation in future studies.

The survival rate of leaves was higher than that of petioles subjected to nine treatments. For petioles, the pre-culture duration, colchicine concentration and exposure time significantly affected the survival rate. Similar conclusions were reported by [25]. However, colchicine concentration was not a significant factor for leaf survival. Interestingly, increased pre-treatment time correlated roughly with decreased survival rates, perhaps because inactivation of in vitro explant cells occurred slowly. The duration of colchicine treatment was the most important factor influencing the survival rate, and leaves exposed to colchicine for 5 days acquired only two tetraploids.

Unsynchronised cell divisions may lead to the induction of mixoploids. Mixoploid induction has been reported in Ranunculus asiaticus [14], Echinacea purpurea [18], and Pyrus pyrifolia N. cv. Hosui [26]. Mixoploid induction always accompanies tetraploid induction, and the in vitro regeneration rate of mixoploids was markedly lower than that obtained directly from treated seeds and shoot tips. Although a higher rate of mixoploid induction occurs during direct regeneration from organs versus from somatic embryos, somatic embryogenesis is often limited by its high threshold of regeneration. We hypothesise that increasing the concentration of cytokinin, and selecting younger and more robust colchicine-treated explants, might improve the efficiency of tetraploid induction. Sivolapov and Blagodarova reported that stable mixoploids in poplar showed growth advantages in field observations [27].

In this study, we explored conditions that were conducive for sweetgum polyploidy breeding. Future studies will be aimed at optimising the treatment conditions and regeneration system for other genotypes. In addition, as various regeneration systems have been successfully established in Liquidambar $[5,20,28]$, our future studies will incorporate other regeneration systems besides the leaf and petiole to induce polyploidy sweetgum.

\section{Conclusions}

To the best of our knowledge, this is the first report of in vitro tetraploid induction from leaf and petiole explants of hybrid sweetgum (L. styraciflua $\times$ L. formosana). This method is effective, not limited by flowering period and easy to operate. In the future, this method could be used for tetraploid induction in multiple genotypes, and these tetraploid plants will be observed and measured continuously with the aim of selecting fast growing, high biomass, strong resistance, superior sweetgum with peculiar ornamental value. Furthermore, hybrid tetraploid sweetgum could be 
a potential source for the promotion of sweetgum breeding and producing triploids by crossing with diploids.

Acknowledgments: This work was supported by National Key R\&D Program of China (2017YFD0600404), Medium and Long Scientific Research Project for Young Teachers in Beijing Forestry University (2015ZCQ-SW-02), the Project of National Natural Science Foundation of China (31370658), "948" Project of China (2014-4-59), Program for Changjiang Scholars and Innovative Research Team in University (IRT13047), and the Project of Beijing Gardening and Greening Bureau (CEG-2016-01).

Author Contributions: Jinfeng Zhang, Bailian Li and Jian Zhao contributed to the experiment design; Yadong Zhang, Xuezheng Liu and Wei Yuan contributed to the collection of seeds; Shuaizheng Qi and Xiaoqi Wang contributed to hybridization; Zewei Wang contributed to the analysis of the ploidy level; Yan Zhang contributed to the induction of tetraploids, paper writing and other aforementioned works.

Conflicts of Interest: The authors declare no conflict of interest.

\section{References}

1. Harlow, W.M.; Harrar, E.S.; Hardin, J.W.; White, F.M. Textbook of Dendrology, 8th ed.; McGraw-Hill: New York, NY, USA, 1996; p. 534.

2. Merkle, S.A.; Neu, K.A.; Battle, P.J.; Bailey, R.L. Somatic embryogenesis and plantlet regeneration from immature and mature tissues of sweetgum (Liquidambar styraciflua). Plant Sci. 1998, 132, 169-178. [CrossRef]

3. Zheng, Y.Q.; Pan, B.; Itohl, T. Chemical induction of traumatic gum ducts in Chinese sweetgum, Liquidambar formosana. IAWA J. 2015, 36, 58-68.

4. Santamour, F.S. Interspecific hybridization in Liquidambar. For. Sci. 1972, 18, 23-26.

5. Vendrame, W.A.; Holliday, C.P.; Merkle, S.A. Clonal propagation of hybrid sweetgum (Liquidambar styraciflua $\times$ L. formosana) by somatic embryogenesis. Plant Cell Rep. 2001, 20, 691-695.

6. Song, Q.; Chen, Z.J. Epigenetic and developmental regulation in plant polyploids. Curr. Opin. Plant Biol. 2015, 24, 101-109. [CrossRef] [PubMed]

7. Tamayo-Ordóñez, M.C.; Espinosa-Barrera, L.A.; Tamayo-Ordóñez, Y.J.; Ayil-Gutiérrez, B.; Sánchez-Teyer, L.F. Advances and perspectives in the generation of polyploidy plant species. Euphytica 2016, 209, 1-22. [CrossRef]

8. Xu, C.P.; Huang, Z.; Liao, T.; Li, Y.; Kang, X.Y. In vitro tetraploid plants regeneration from leaf explants of multiple genotypes in Populus. Plant Cell Tissue Organ Cult. 2016, 125, 1-9. [CrossRef]

9. Cai, X.; Kang, X.Y. In vitro tetraploid induction from leaf explants of Populus pseudo-simonii Kitag. Plant Cell Rep. 2011, 30, 1771-1778. [CrossRef] [PubMed]

10. Tang, Z.Q.; Chen, D.L.; Song, Z.J.; He, Y.C.; Cai, D.T. In vitro induction and identification of tetraploid plants of Paulownia tomentosa. Plant Cell Tissue Organ Cult. 2010, 102, 213-220. [CrossRef]

11. Wu, J.H.; Mooney, P. Autotetraploid tangor plant regeneration from in vitro Citrus somatic embryogenic callus treated with colchicine. Plant Cell Tissue Organ Cult. 2002, 70, 99-104. [CrossRef]

12. Yang, X.M.; Cao, Z.Y.; An, L.Z.; Wang, Y.M.; Fang, X.W. In vitro tetraploid induction via colchicine treatment from diploid somatic embryos in grapevine (Vitis vinifera L.). Euphytica 2006, 152, 217-224. [CrossRef]

13. Stanys, V.; Weckman, A.; Staniene, G.; Duchovskis, P. In vitro induction of polyploidy in japanese quince (Chaenomeles japonica). Plant Cell Tissue Organ Cult. 2006, 84, 263-268. [CrossRef]

14. Dhooghe, E.; Denis, S.; Eeckhaut, T.; Reheul, D.; Van Labeke, M. In vitro induction of tetraploids in ornamental Ranunculus. Euphytica 2009, 168, 33-40. [CrossRef]

15. Wu, J.H.; Ferguson, A.R.; Murray, B.G. Manipulation of ploidy for kiwifruit breeding: In vitro chromosome doubling in diploid Actinidia chinensis. Planch. Plant Cell Tissue Organ Cult. 2011, 106, 503-511. [CrossRef]

16. Zhang, Q.Y.; Luo, F.X.; Liu, L.; Guo, F.C. In vitro induction of tetraploids in crape myrtle (Lagerstroemia indica L.). Plant Cell Tissue Organ Cult. 2010, 101, 41-47.

17. De Carvalho, J.F.R.P.; de Carvalho, C.R.; Otoni, W.C. In vitro induction of polyploidy in annatto (Bixa orellana). Plant Cell Tissue Organ Cult. 2005, 80, 69-75. [CrossRef]

18. Nilanthi, D.; Chen, X.L.; Zhao, F.C.; Yang, Y.S.; Wu, H. Induction of tetraploids from petiole explants through colchicine treatments in Echinacea purpurea L. J. Biomed. Biotechnol. 2009. [CrossRef] [PubMed]

19. Brand, M.H.; Lineberger, R.D. In vitro adventitious shoot formation on mature-phase leaves and petioles of Liquidambar styraciflua L. Plant Sci. 1988, 57, 173-179. [CrossRef] 
20. Kim, M.K.; Sommer, H.E.; Bongarten, B.C.; Merkle, S.A. High-frequency induction of adventitious shoots from hypocotyl segments of Liquidambar styraciflua L. by thidiazuron. Plant Cell Rep. 1997, 16, 536-540. [CrossRef]

21. Xu, L.; Liu, G.F.; Bao, M.Z. Adventitious shoot regeneration from in vitro leaves of formosan sweetgum (Liquidambar formosana L.). Hortscience 2007, 42, 721723.

22. Lloyd, G.; McCown, B. Commercially feasible micropropagation of mountain laurel; Kalmia latifolia; by use of shoot-tip culture. Proc. Int. Plant Propag. Soc. 1980, 30, 421-427.

23. Erlanson, E.W. Cytological Conditions and Evidences for Hybridity in North American Wild Roses. Bot. Gaz. 1929, 87, 443-506. [CrossRef]

24. Carr, D.H.; Walker, J.E. Carbol fuchsin as a stain for human chromosomes. Stain Technol. 1961, 36, $233-236$. [CrossRef] [PubMed]

25. Głowacka, K.; Jeżowski, S.; Kaczmarek, Z. In vitro induction of polyploidy by colchicine treatment of shoots and preliminary characterisation of induced polyploids in two Miscanthus species. Ind. Crops Prod. 2010, 32, 88-96. [CrossRef]

26. Kadota, M.; Niimi, Y. In vitro induction of tetraploid plants from a diploid Japanese pear cultivar (Pyrus pyrifolia N. cv. Hosui). Plant Cell Rep. 2002, 21, 282-286.

27. Sivolapov, A.I.; Blagodarova, T.A. Different levels of mixoploiy in hybrid poplars. In Cytogenetic Studies of Forest Trees and Shrub Species; Borzan, Z., Schlarbaum, S.E., Eds.; Faculty of Foresty Inc.: Zagreb, Croatia, 1997; pp. 311-316.

28. Merkle, S.A.; Battle, P.J.; Ware, G.O. Factors influencing production of inflorescence-derived somatic seedlings of sweetgum. Plant Cell Tissue Organ Cult. 2003, 73, 95-99. [CrossRef]

(C) 2017 by the authors. Licensee MDPI, Basel, Switzerland. This article is an open access article distributed under the terms and conditions of the Creative Commons Attribution (CC BY) license (http://creativecommons.org/licenses/by/4.0/). 